\title{
The geographical distribution of the shadow economy and its decline in Uzbekistan
}

\author{
Umida Sangirova ${ }^{1, *}$, Bekmukhammad Tursunov $^{2}$, Shakhzod Shayakubov ${ }^{2}$, \\ Iskandar Yunusov ${ }^{1}$, and Dilfuza Bababekova ${ }^{2}$ \\ ${ }^{1}$ Tashkent institute of irrigation and agricultural mechanization engineers, 39, Kari Niyazov \\ street, 100000, Tashkent, Uzbekistan \\ ${ }^{2}$ Tashkent Institute of Finance, 60A, A.Temur Street, 100000 , Tashkent, Uzbekistan
}

\begin{abstract}
The topic of this research is to study the geographical distribution of the shadow economy around the world, and in particular to study its state in the territory of the Republic of Uzbekistan. The shadow economy is widespread in all countries of the world. The research topic is very relevant at the moment, during the period of digitalization of the economies of the countries of the world. The relevance of the study of the development of the shadow economy in the world is associated with the unstable, transitional state of the countries of the world. This instability is associated with the transition from industrial to post-industrial society. In the study of the theoretical part, the methods of analysis, grouping, sampling were used, in the study of the empirical part, the observation method, the method of expert assessment, comparative analysis were applied. Using modern research methods, we were able to reveal the most common causes of the shadow economy. The object of the research is the state of the economy of the Republic of Uzbekistan; the subject of the research is the factors influencing the emergence of the shadow economy, both in developed countries and in developing countries. Having studied the reasons for the emergence of the shadow economy in the territory of the Republic of Uzbekistan, the authors put forward proposals for their reduction, in order to improve the state of the country's comprehensive development.
\end{abstract}

\section{Introduction}

The shadow economy means a part of the economy that is outside the field of vision of the state. The shadow economy is not controlled by state bodies, it escapes the attention of state bodies, thereby damaging the development of the economic system of the Republic. If the share of the shadow economy exceeds the required norm, then the effectiveness of the regulation policy decreases [1]. Due to the high share of the shadow economy, the main burden goes to the official part of the economy, in the form of tax and regulatory burdens with increased tax rates and excessive management mechanism. This, in turn, increases the costs of staying in the official part of the economy, thereby provoking the growth of the shadow sector.

\footnotetext{
*Corresponding author: indira91@inbox.ru
} 


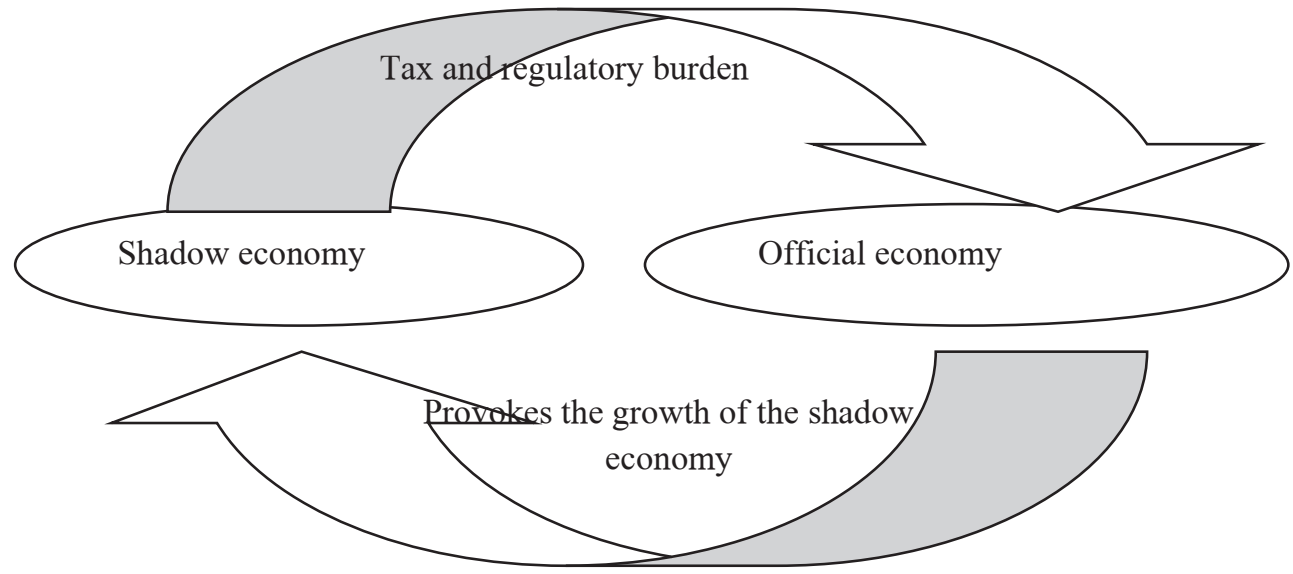

Fig. 1. The relationship between the shadow and the official part of the economy.

The concept of "shadow economy" entered science in the early 1970s, explaining the concealment of income, tax evasion and illegal ways of extracting them [2,3]. Although this concept has existed for a very long time, interest in it in the scientific community has increased in recent decades.

There are three important elements in the shadow economy, as we see in Figure 2.

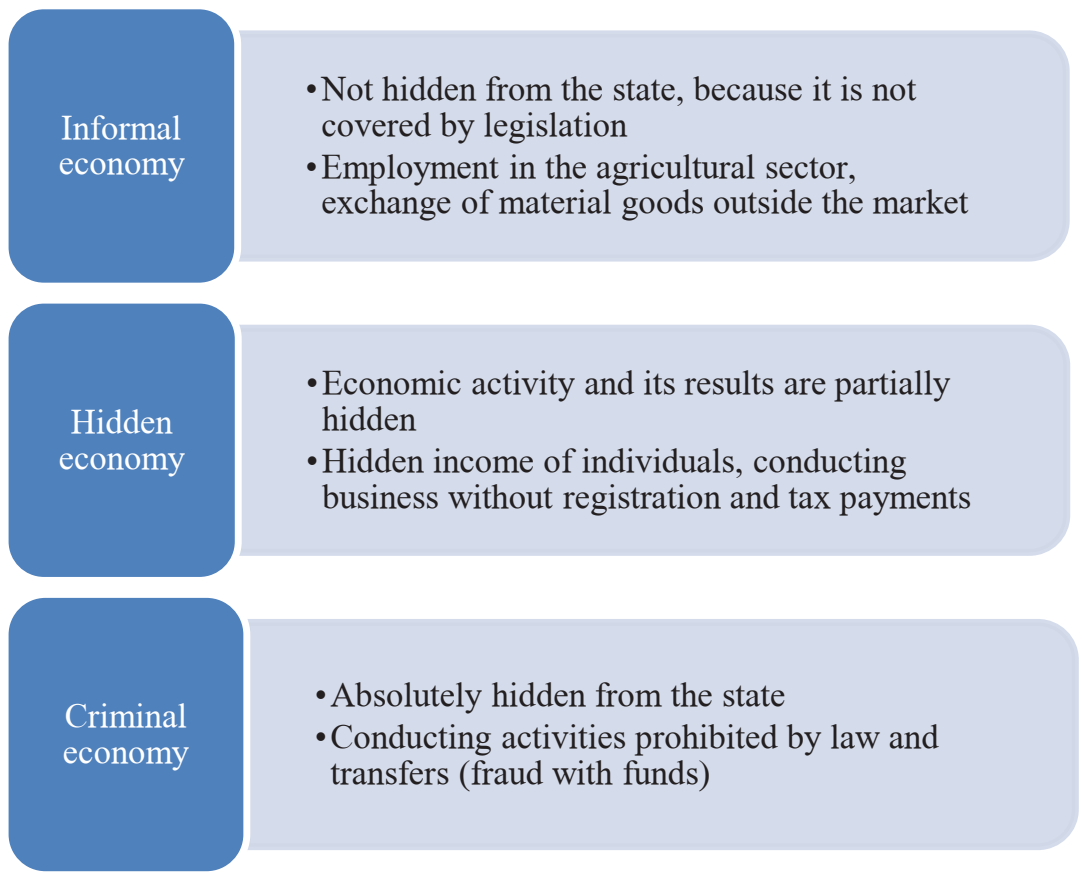

Fig. 2. Elements of the shadow economy.

\section{Methods}

When studying the topic of the shadow economy, a large number of methods were used. Some of the most convenient methods for studying a topic are the method of analysis, 
grouping, sampling; in the study of the empirical part, the observation method, the method of expert assessment, and comparative analysis were applied. The chosen methods contribute to a more extensive study of the material. [5]

The shadow economy, as the subject of the study, is very extensive, which causes a slight difficulty in studying it. There are many of the most popular methods to determine the extent of the shadow economy:

1) Direct method - it calculates the scale of the shadow economy through surveys. The disadvantage of this method is the lack of information reliability.

2) Macroeconomic method, based on indicators of the System of National Accounts. It is based on the calculation of the volume of the shadow economy, by the method of the difference between income and expenditure of gross national income.

3) Monitoring the employment rate of the population. As a rule, activation, an increase in the labor force is a stable indicator, but if its decrease is observed, then this most likely means an outflow of labor force into the shadow part of the economy.

4) MIMIC method. This method includes all of the above methods to create an econometric model.

According to the experience of developed countries of the world, the methods of "demand for cash" and "physical costs" are also actively used. The method of "cash" is based on transactions carried out with the participation of cash, according to this method, all transactions carried out in the shadow market, as a rule, take place with the use of cash to hide this state $[8,9]$. The disadvantage of this method is the lack of an accurate indicator of transactions carried out for cash.

\section{Results}

The reasons for the appearance of the shadow economy are the crisis in the economy, high taxes, corruption of officials, excessive bureaucracy and many others. Several groups of factors can be distinguished, due to which some types of economic activity move from the official to the shadow part of the economy. [10,11]

Group I "Financial and economic factors":

- deficiencies in tax administration

- too high taxes encourage entrepreneurs to run their business outside the official market

- ineffective distribution of state finances, corruption in the provision of tax and other benefits for individual entities

Group II "Legal Factors":

- deficiencies in the legislative framework, due to which illegal activities develop and crime and impunity increase

- corruption in the judiciary and law enforcement system

- distrust of the state due to poor protection of private property

Group III "Administrative Factors":

- inefficiency of government administration and poor discipline between the levels of government

- complicated procedure for starting and running a business

- non-professionalism of employees of state power and administration

Group IV "Social and political factors":

- insufficient level of economic and financial literacy of society

- uncertainty of entrepreneurs in the stability of state economic policy

- the existence of vulnerable groups of the population, their vulnerability during a crisis in the state [12] 


\section{Discussion}

According to the analysis of experts, Uzbekistan belongs to the group of countries with a high level of the shadow economy. Its share in the gross domestic product in 2020 amounted to about $48 \%$, or 245 trillion soums. In 2020, the Republic of Uzbekistan ranks 114th out of 186 countries in the world in the Index of Economic Freedom, scoring 57.2 points out of 100. This indicator is very low, which indicates a high share of the shadow economy in the country. [13] The Index of Economic Freedom most clearly represents the share of the shadow economy in the country's economic system. The index of economic freedom consists of 12 components: property rights, judicial efficiency, government integrity, tax burden, government spending, fiscal health, free enterprise, labor freedom, monetary freedom, free trade, investment freedom, and financial freedom.

On October 30, 2020, the President of the Republic of Uzbekistan Sh.Mirziyoyev signed a decree "On organizational measures to reduce the shadow economy and increase the efficiency of tax authorities" [14]. According to this decree, from January 1, 2021, the following measures will be taken to reduce the share of the shadow economy:

* Until January 1, 2022, the profits of small business entrepreneurs in the catering sector, obtained using bank cards and contactless payments, will not be included in the total income for the transition to the payment of generally established taxes

* Individuals engaged in real estate activities, reduce the turnover tax rate from $25 \%$ to $13 \%$

* Persons involved in construction are allowed to hire workers without concluding an agreement, and pay them in cash, the amount of payment issued must not exceed $10 \%$ of the wage bill (excluding the amount of social tax). Construction organizations must report on workers hired without a contract, indicating them in the register with a specification of wages.

Until January 1, 2022, the tax authorities will notify entrepreneurs under the President of Uzbekistan about the appointment of a tax audit and conducting field audits. Foreign expert advisors will be provided to the chairmen of the state tax committee to address the issues of reducing the shadow economy.

A sector is being created to reduce the share of the shadow turnover in the economy and form additional sources of budget revenues, under the Ministry of Economic Development and Poverty Reduction - the Department for Analysis of the Shadow Economy, in the State Tax Committee - the Department of Tax Control, in the Ministry of Finance - a department for organizing work to reduce the shadow economy.

In 2020, about 100 billion soums were allocated to equip the Tax Authorities Data Center with modern equipment and software.

\section{Conclusions}

We have given the following recommendations for getting out of the shadow economy in Uzbekistan:

1. Having studied the world experience, it should be noted that when the number of electronic payments increases, the level of the shadow economy in the country's GDP decreases proportionally. Transactions will be declared, the owners of the services provided by the services of electronic payments, whose benefits exceed the costs of declaring transactions, will no longer be on the market of the shadow economy.

2. One of the most important way out is to simplify the tax system. You can diversify the payment of VAT for different goods. Take Germany as an example, where VAT is $19 \%$, and for food it is $7 \%$. 
3. Increasing investment in the country's public capital. If we introduce an international program on the concept of corporate social responsibility (CSR), hold seminars, talks, lectures, bringing together government bodies and the population, it will be possible to gain trust and proposals for improving the country's economy. [15]

4. Application of the Flexicurity model. As a basis, we can take the experience of Germany, which, using this model, reduced the shadow economy in 2003-2005 by almost 40 billion euros. According to this model, conditions for part-time employment are created, such as simplification of tax obligations, provision of social insurance, and reduction of document circulation.

\section{References}

1. V.Yu. Burov, Shadow economy and small business: theoretical and methodological foundations of the study (ZabGU, Chita, 2014)

2. A.V. Kostin, Bulletin of the Novosibirsk State University. Series: Socio-economic sciences 4, 33-43 (2011)

3. M.I. Nikolaeva, A.Yu. Shevyakov, Economics and Mathematical methods, 926-935 (1990)

4. M. Hassan, F. Schneider, Size and Development of the Shadow Economies of 157 Countries Worldwide: Updated and New Measures from 1999 to 2013 (Bonn, 2016)

5. F. Schneider, D. Enste, J. of Econ. Literature 1, 81 (2000)

6. F. Schneider, Increasing Shadow Economies All Over the World - Fiction or Reality? A Survey of the Global Evidence of their Size and of their Impact from 1970 to 1995 , http://www.economics.uni-linz.ac.at/Members/ Schneider/EnstSchn98.html

7. B.S. Frey, F. Schneider, Informal and Underground Economy (2000)

8. H. Ahumada, F. Alvaredo, A.J. Canavese, The Demand for Currency approach and the size of the shadow economy: A critical assessment (2006)

9. P. Cagan, The Demand for Currency Relative to the Total Money Supply, Journal of Political Economy (1958)

10. V. Tanzi, Underground Economy and Tax Evasion in the United States: Estimates and Implications (1982)

11. S.B. Chernov, Bulletin of the University (State University of Management) 13, 101108 (2012)

12. A. Nesterov, A. Vakurin, Voprosy ekonomiki 1, 135-142 (1995)

13. Macroeconomic indicators of Uzbekistan, https://stat.uz/ru/2-uncategorised/6693makroekonomicheskie-pokazateli2/

14. Decree of the President of the Republic of Uzbekistan Sh.Mirziyoyev UP -6098 of 30.10.2020

15. A.I. Smirnov, Economic sciences 4 (2008) 